\title{
Germination characteristic of Silphium perfoliatum L. seeds
}

\author{
Keimfähigkeitscharakteristik von Silphium perfoliatum L.-Samen
}

\author{
Markus Gansberger ${ }^{1 *}$, Hans-Peter Stüger ${ }^{2}$, Manfred Weinhappel ${ }^{1}$, Karl Moder $^{3}$, Peter Liebhard ${ }^{4}$, \\ Philipp von Gehren ${ }^{1}$, Josef Mayr ${ }^{1}$, Andreas Ratzenböck ${ }^{1}$
}

\author{
${ }^{1}$ Austrian Agency for Health and Food Safety, Institute for Seed and Propagating Material, Phytosanitary Service and Apiculture, \\ Spargelfeldstraße 191, 1220 Vienna, Austria \\ ${ }^{2}$ Austrian Agency for Health and Food Safety, Data, Statistics and Risk Assessment, Statistics and Analytical Epidemiology, Beethovenstraße 8, \\ 8010 Graz, Austria \\ ${ }^{3}$ University of Natural Resources and Life Sciences Vienna (BOKU), Department of Landscape, Spatial and Infrastructure Sciences, Institute of \\ Applied Statistics and Computing, Peter-Jordan-Straße 82, 1190 Vienna, Austria \\ ${ }^{4}$ University of Natural Resources and Life Sciences Vienna (BOKU), Department of Crop Sciences, Division of Agronomy, Gregor-Mendel- \\ Straße 33, 1180 Vienna, Austria \\ * Corresponding author: markus.gansberger@ages.at
}

Received: 8 March 2017, received in revised form: 8 May 2017, accepted: 12 May 2017

\begin{abstract}
Summary
Silphium perfoliatum L. is a perennial and flowering crop that has been investigated in recent years for its potential as an energy plant, particularly for biogas production. A stand establishment by sowing of seeds is complicated, owing to the low germination capacity of untreated S. perfoliatum L. seeds. Consequently, germination experiments were carried out with two- to four-factor levels to determine the effect of selected factors (medium, pretreatment, light, temperature, prechilling) on dormancy and germination of $S$. perfoliatum L. seeds and to achieve maximum germination rate. All factors had a highly significant effect on germination. Germination experiments displayed a primary and physiological dormancy. Germination could be significantly increased by using a $0.05 \% \mathrm{GA}_{3}$ solution during the imbibition phase, a light-dark cycle, alternating temperatures between $20^{\circ} \mathrm{C}$ and $30^{\circ} \mathrm{C}$, and a wet stratification for seven days at $0^{\circ} \mathrm{C}$. The experiments helped to fully exploit the germination potential and to develop a germination test method for $S$. perfoliatum L.
\end{abstract}

Keywords: bioenergy, cup plant, dormancy, seed production, seed treatment

\section{Zusammenfassung}

Silphium perfoliatum L. ist eine ausdauernde und blühende Pflanze, die in den letzten Jahren hinsichtlich ihres Potentials als Energiepflanze für die Biogasproduktion untersucht wurde. Eine gesicherte Bestandesbegründung mittels Saat ist aufgrund der geringen Keimfähigkeit von unbehandelten S. perfoliatum L.-Samen schwierig. Folglich wurden Keimversuche mit zwei bis vier Faktorstufen durchgeführt, um die Wirkung ausgewählter Faktoren (Medium, Vorbehandlung, Licht, Temperatur, Vorkühlung) auf die Dormanz und die Keimung von S. perfoliatum L.-Samen zu bestimmen und die maximale Keimfähigkeit zu erreichen. Alle untersuchten Faktoren hatten einen signifikanten Effekt auf die Keimung. Die Keimfähigkeitsversuche ergaben eine primäre und physiologische Dormanz. Die Keimfähigkeit wurde durch den Einsatz einer 0,05\% $\mathrm{GA}_{3}$-Lösung während der Quellungsphase, eines Licht- und Dunkelwechsels, einer alternierenden Temperatur zwischen 20 und $30^{\circ} \mathrm{C}$ und einer nassen Stratifikation von sieben Tagen bei $0^{\circ} \mathrm{C}$ signifikant erhöht. Damit wurde das Keimfähigkeitspotential ausgeschöpft und eine Keimfähigkeitsprüfmethode für S. perfoliatum L. entwickelt.

Schlagworte: Bioenergie, Becherpflanze, Dormanz, Saatgutproduktion, Saatgutbehandlung 


\section{Introduction}

Silphium perfoliatum L. is a perennial, tall, yellow flowering $\mathrm{C}_{3}$ plant, characterized by a wide range of valuable practical traits and has been cultivated as a medical, melliferous, fodder, ornamental, and reclamation plant (Niqueux, 1981; Neumerkel and Märtin, 1982; Troxler and Daccord, 1982; Daniel and Rompf, 1994; Kowalski and Wolski, 2005; Kowalski and Kędzia, 2007; Zhang et al., 2010). In recent years, $S$. perfoliatum $\mathrm{L}$. has been of interest as an energy crop, especially for biogas production (Vetter et al., 2010; Bauböck et al., 2014; Mast et al., 2014; Gansberger et al., 2015). The low care requirements (after the first year) compared to annual plants, the high yield potential of the biomass, and the ecological benefits make $S$. perfoliatum $\mathrm{L}$. a valuable renewable raw material (Gansberger et al., 2015). The labor-intensive and expensive planting of pregrown seedlings is currently the common method of stand establishment. Sowing is not feasible owing to a lack of highquality seeds (Bauböck et al., 2014; Franzaring et al., 2015; Gansberger et al., 2015) and inappropriate seed technology. Furthermore, little is known about the germination requirements of $S$. perfoliatum L. (Gansberger et al., 2015). To tap the full potential of the germination capacity, the necessary environmental conditions must be identified and the dormancy, if present, must be broken. According to Sokolov and Gritsak (1972), Troxler and Daccord (1982), and Vetter et al. (2010), untreated seeds of S. perfoliatum L. show a strong dormancy, leading to an uneven and sometimes highly delayed germination. Trölenberg et al. (2012) assumed that there was no dormancy in S. perfoliatum L., but instead, quiescence. Quiescent seeds are not dormant, but are metabolically inactive because of the absence of one or more environmental factors (Bewley, 1997; Baskin and Baskin, 2004).

The aims of this work were to investigate the effect of individual factors and their levels on germination and dormancy and to determine the advisable conditions for germination, as well as to recommend a germination test method to evaluate the full germination capacity of $S$. perfoliatum L. seeds.

\section{Material and methods}

\subsection{Seeds}

Seeds of two different origins were used for the germination experiments. Lot A was harvested in September 2012 in Vienna, Austria $\left(48^{\circ} 15^{\prime} 23^{\prime \prime N}, 16^{\circ} 29^{\prime} 5^{\prime \prime E}\right)$. Lot B was obtained from a harvest in September 2011 in Rheinstetten-Forchheim, Germany ( $\left.48^{\circ} 58^{\prime} 1 " \mathrm{~N}, 8^{\circ} 20^{\prime} 3 " \mathrm{E}\right)$. The viability and the theoretical germination capacity of both seed lots (rep $=4 \times 50)$ were determined by a tetrazolium test, which also counts seeds with a physiological dormancy as viable (Baskin and Baskin, 2014). The germination potential was $97.5 \pm 2.2 \%$ for lot $A$ and $98.5 \pm 0.9 \%$ for lot $\mathrm{B}$, providing an excellent basis for the subsequent tests.

\subsection{Model of the germination experiment}

The experimental design was based on several factors and factor levels. These were chosen based on literature values for germination requirements of achenes, other members of the Asteraceae, the results of preliminary experiments, and the climate conditions of $S$. perfoliatum L.'s natural habitat. A full-factorial randomized design (with a total of 144 combinations) was used with two- to four-factor levels of following factors:

- Medium: pleated paper (PP); top of paper (TP)

- Pretreatment: water; $\mathrm{KNO}_{3}-200 \mathrm{mg} / \mathrm{L} ; \mathrm{GA}_{3}$ (Merck KGaA) - 500 mg/L

- Light (PAR between 400 and $700 \mathrm{~nm}$ ): 24-h light; 12-h light

- Temperature: $20^{\circ} \mathrm{C} ; 30^{\circ} \mathrm{C} ; 20 / 30^{\circ} \mathrm{C}$

- Prechilling: no prechilling; 7 days $/ 10^{\circ} \mathrm{C} ; 7$ days / $5^{\circ} \mathrm{C} ; 7$ days $/ 0^{\circ} \mathrm{C}$

Each combination corresponded to a germination test method and was tested with seed lots A and B in a growth chamber (from the Kühlanlagenbau Fritz Lachmayr GesmbH, Kremsmünster, Austria). Based on sample size calculation (power 90\%, $\alpha=5 \%, \delta=2 \%$ ), 144 analyses with eight replicates each were carried out for the two lots. Overall, 2304 observations $(144 \times 2 \times 8)$ were used and each replication consisted of 50 seeds.

The evaluation was carried out after 7, 14, and 21 days. The seedlings were classified as normal seedlings, abnormal seedlings, or un-germinated seeds according to the International Rules for Seed Testing (ISTA, 2015). However, for evaluating dormancy, normal and abnormal seeds were both counted as germinated seeds.

\subsection{Statistical analyses}

The data set was analyzed with the statistics software SPSS V22.0. The requirements of the statistical tests were 
checked before and were fulfilled. Residuals were checked for normal distribution and homoscedasticity by using residual plots and statistical tests. An analysis of variance (ANOVA) was carried out with a mixed model approach to determine if the selected factors and their two-way interactions had a significant effect on germination capacity. The factors "medium, pretreatment, light, temperature and prechilling" were defined as fixed effects and the seed lot was defined as random effect. The significance level was chosen as 95\%. Additionally, post-hoc analysis (TukeyHSD) was applied for significant factors to separate the most effective factor levels.

Finally, the most promising factor levels were combined in a recommended germination test method and validated with the predicted expected values of the linear model with main effects and interactions.

\section{Results and discussion}

\subsection{Germination capacity}

The results of the germination capacity experiments ranged between 0 and $96 \%$ germinated seeds. With an unfavorable combination of factors, no seeds germinated, and with favorable combinations, up to $96 \%$ germinated. This effectively corresponds to the full germination potential of around $98 \%$, which was determined in advance by a tetrazolium test. In addition, these tests showed that the embryos were fully developed and that water could enter through the seed coat to the embryo. Thus, a morphological and physical dormancy could be excluded.

\subsection{Effect of selected factors and factor levels on germination}

All main factors and also almost all two-way interactions had a highly significant effect on germination (Table 1). The interaction of the individual factors caused a large degree of fluctuation. The standard deviation was between $20 \%$ and $30 \%$ for all factors.

Effect of various media on germination: The mean value of germinated seeds with PP was about $1.7 \%$ higher than with TP (Table 2). Seeds in TP showed fungal infections. In contrast, the folds in the pleated paper (PP) served as a barrier, preventing fungi from growing from one seed to the next. PP seems better suited for the germination of S. perfoliatum L. seeds with their flat shape and large seed surface.
Effect of various pretreatments on germination: $\mathrm{GA}_{3}$ and $\mathrm{KNO}_{3}$ solutions can affect the metabolic activity of seeds (Baskin and Baskin, 2004). Our experiments show that the treatment with $\mathrm{GA}_{3}$ and $\mathrm{KNO}_{3}$ solutions led to significantly higher germination than the untreated control with water (Table 2 and Figure 1). The greatest effect on germination capacity was achieved with $\mathrm{GA}_{3}$. GA $\mathrm{GA}_{3}$ has the opposite effect to abscisic acid (ABA) and the exact ratio of $\mathrm{GA}_{3}$ to $\mathrm{ABA}$ determines, on a plant-hormone level, whether a seed will start to germinate or remain dormant. ABA accumulates in the embryo during seed ripening and is responsible for primary dormancy (Kucera et al., 2005). In contrast, $\mathrm{GA}_{3}$ induces growth of the embryo and increases the availability of nutrients (Koornneef et al., 2002; Hilhorst, 1995). The ratio of $\mathrm{GA}_{3}$ and ABA at $S$. perfoliatum L. seeds has probably been shifted by adding $\mathrm{GA}_{3}$ solution and consequently the germination capacity increased. This effect suggests the presence of a physiological dormancy. The experiments of Vetter et al. (2010) and Trölenberg et al. (2012) with $S$. perfoliatum L. seeds using

Table 1. Results of the mixed model analysis (ANOVA)

Tabelle 1. Ergebnisse der gemischten Modellanalyse (ANOVA)

\begin{tabular}{|c|c|c|}
\hline & $F$ & $p$-value \\
\hline Medium & 14.6 & $<0.001$ \\
\hline Light & 221.3 & $<0.001$ \\
\hline Temperature & 6063.3 & $<0.001$ \\
\hline Pretreatment & 528.0 & $<0.001$ \\
\hline Prechilling & 540.7 & $<0.001$ \\
\hline Lot & 3213.7 & $<0.001$ \\
\hline Medium $\times$ light & 14.5 & $<0.001$ \\
\hline Light $\times$ prechilling & 18.0 & $<0.001$ \\
\hline Light $\times$ pretreatment & 2.7 & 0.065 \\
\hline Light $\times$ temperature & 13.9 & $<0.001$ \\
\hline Medium $\times$ prechilling & 4.3 & 0.005 \\
\hline Medium $\times$ pretreatment & 22.1 & $<0.001$ \\
\hline Medium $\times$ temperature & 75.3 & $<0.001$ \\
\hline Pretreatment $\times$ prechilling & 11.8 & $<0.001$ \\
\hline Temperature $\times$ prechilling & 39.8 & $<0.001$ \\
\hline Temperature $\times$ pretreatment & 11.5 & $<0.001$ \\
\hline
\end{tabular}

The seeds from lot A had a germination capacity (overall factors and factor levels) of $34.0^{\mathrm{a}} \pm 26.1 \%$. Lot B, with $56.2^{\mathrm{b}} \pm 27.9 \%$, had significantly higher germination rates than lot $\mathrm{A}$. 
Table 2. Mean value and standard deviation of germinated seeds for selected factor levels

Tabelle 2. Mittelwert und Standardabweichung gekeimter Samen für ausgewählte Faktorstufen

\begin{tabular}{|c|c|c|c|c|}
\hline Factors & Factor levels & & & \\
\hline Medium & $\begin{array}{l}\text { Pleated paper (PP) } \\
48.3^{\mathrm{b}} \pm 30.7 \%\end{array}$ & $\begin{array}{l}\text { Top of paper (TP) } \\
46.6^{\mathrm{a}} \pm 30.4 \%\end{array}$ & & \\
\hline Pretreatment & $\begin{array}{l}\text { Water } \\
39.3^{a} \pm 29.8 \%\end{array}$ & $\begin{array}{l}\mathrm{KNO}_{3}(200 \mathrm{mg} / \mathrm{L}) \\
47.0^{\mathrm{b}} \pm 30.6 \%\end{array}$ & $\begin{array}{l}\mathrm{GA}_{3}(500 \mathrm{mg} / \mathrm{L}) \\
55.9^{\mathrm{c}} \pm 28.9 \%\end{array}$ & \\
\hline Light & $\begin{array}{l}\text { 24-hours light } \\
44.3^{\mathrm{a}} \pm 29.4 \%\end{array}$ & $\begin{array}{l}\text { 12-hours light } \\
50.6^{\mathrm{b}} \pm 31.4 \%\end{array}$ & & \\
\hline Temperature & $\begin{array}{l}20^{\circ} \mathrm{C} \\
18.6^{a} \pm 18.7 \%\end{array}$ & $\begin{array}{l}30^{\circ} \mathrm{C} \\
48.5^{b} \pm 21.0 \%\end{array}$ & $\begin{array}{l}20 / 30^{\circ} \mathrm{C} \\
75.2^{\mathrm{c}} \pm 20.2 \%\end{array}$ & \\
\hline Prechilling & $\begin{array}{l}\text { No prechilling } \\
33.4^{a} \pm 26.6 \%\end{array}$ & $\begin{array}{l}7 \text { days } / 10^{\circ} \mathrm{C} \\
48.8^{\mathrm{b}} \pm 31.1 \%\end{array}$ & $\begin{array}{l}7 \text { days } / 5^{\circ} \mathrm{C} \\
51.8^{\mathrm{c}} \pm 29.9 \%\end{array}$ & $\begin{array}{l}7 \text { days } / 0^{\circ} \mathrm{C} \\
55.7^{\mathrm{d}} \pm 29.6 \%\end{array}$ \\
\hline
\end{tabular}

The factor levels marked with different letters $(\mathrm{a}-\mathrm{d})$ are significantly different $(\alpha=5 \%)$ by Tukey-HSD test. See additional data in Table 4.

$\mathrm{GA}_{3}$ solution also showed a germination capacity close to the theoretically possible maximum.

Effect of 12 hours and 24 hours light on germination: Light and its intensity can have a substantial effect on dormancy and germination (Oh et al., 2006). Light had a positive effect on the germination of $S$. perfoliatum L. during the preliminary experiments. To investigate this effect, 12and 24-hour light variants were tested. The 12-hour lightdark cycle with a light intensity between 400 and 1200 lux resulted in significantly higher germination capacities than the 24-hour light variant (Table 2).

Effect of various temperatures on germination: Favorable environmental conditions, like specific temperature ranges, are important for germination; otherwise the seeds cannot germinate (Baskin and Baskin, 2004) or fall into secondary dormancy (Hilhorst, 1998; Finch-Savage and Leubner-Metzger, 2006). If seeds have physiological dormancy, alternating temperatures can be used to break their dormancy (Long et al., 2014).

Temperature had the greatest effect on germination capacity over all the five factors in our experiment. The differences between the temperature variants were highly significant. As Table 2 and Figure 1 show, the temperature cycles of $20 / 30^{\circ} \mathrm{C}$ every 12 hours showed distinctly more germination than constant temperatures at $20^{\circ} \mathrm{C}$ or $30^{\circ} \mathrm{C}$. In combination with the $\mathrm{GA}_{3}$ solution, an average germination capacity of over $85 \%$ was achieved.

Trölenberg et al. (2012) extensively studied the effect of various constant and changing temperatures on the germi- nation of $S$. perfoliatum $\mathrm{L}$. seeds at a temperature-gradient germination table. The results showed that germination was positively influenced by higher temperatures up to $30^{\circ} \mathrm{C}$ and by alternating temperatures with higher amplitude.

Effect of various prechilling variants on germination: Several decades ago, Sokolov and Gritsak (1972) and Troxler and Daccord (1982) recommended sowing S. perfoliatum L. seeds in late autumn, at the latest 15-20 days before the first night frost, using freshly gathered seeds or in spring with seeds that had been stratified for 2 months. Accordingly, the factor "prechilling" was included in the model, as prechilling is particularly suitable to break the physiological dormancy (Long et al., 2014).

The results confirmed that prechilling has a positive effect on the germination capacity. The germination capacity of the variants with prechilling $\left(7\right.$ days $/ 10^{\circ} \mathrm{C} ; 7$ days $/ 5^{\circ} \mathrm{C}$; 7 days $/ 0^{\circ} \mathrm{C}$ ) was highly significantly higher than the untreated control (no prechilling). The differences between the individual prechilling temperatures were not pronounced, but still significant. Therefore, a prechilling phase at $0^{\circ} \mathrm{C}$ over 7 days is advisable to achieve a high germination capacity and to break the physiological dormancy.

The results are consistent with the conclusions of Vetter et al. (2010) and Trölenberg et al. (2012). They recommend a prechilling phase at $5^{\circ} \mathrm{C}$ over 5 and 7 days respectively. Franzaring et al. (2014) used a four-week prechilling period in climate chambers for their growth experiments with $S$. perfoliatum $\mathrm{L}$. The temperatures varied between $3^{\circ} \mathrm{C}$ and $11^{\circ} \mathrm{C}$, causing stratification and breaking of the seed dormancy. 


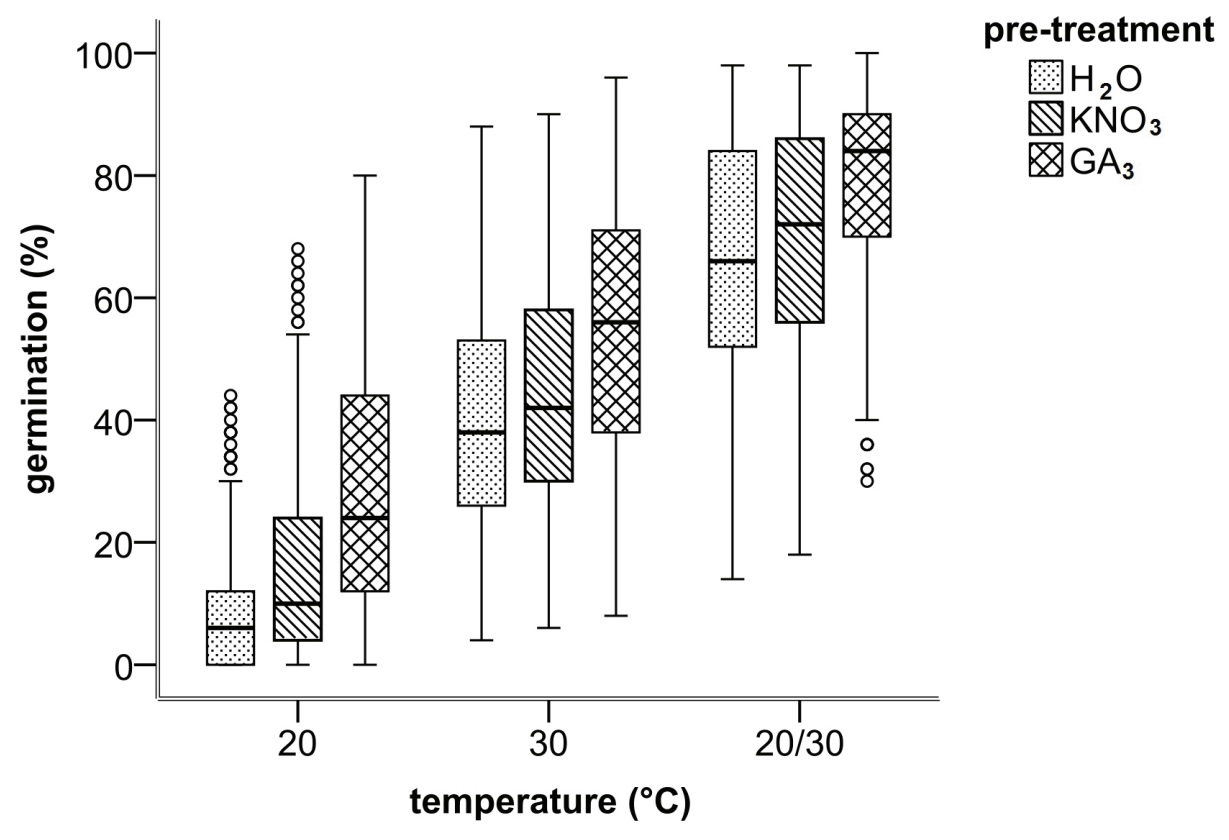

Figure 1. Effect of various temperatures $\left(20^{\circ} \mathrm{C} ; 30^{\circ} \mathrm{C} ; 20 / 30^{\circ} \mathrm{C}\right)$ and pretreatments $\left(\mathrm{H}_{2} \mathrm{O} ; \mathrm{KNO}_{3} ; \mathrm{GA}_{3}\right)$ on the germination of Silphium perfoliatum L.

Abbildung 1. Effekt von unterschiedlichen Temperaturen $\left(20^{\circ} \mathrm{C} ; 30^{\circ} \mathrm{C} ; 20 / 30^{\circ} \mathrm{C}\right)$ und Vorbehandlungen $\left(\mathrm{H}_{2} \mathrm{O}_{3} \mathrm{KNO}_{3} ; \mathrm{GA}_{3}\right)$ auf die $\mathrm{Keimfähig}$ keit von Silphium perfoliatum L.

\subsection{Germination characteristic and germination test method of $S$. perfoliatum $\mathrm{L}$.}

The most promising factor levels were combined in a germination test method, which allows the assessment of the germination capacity of S. perfoliatum L. seeds (Table 3 ). These results were confirmed by using the predicted outcome of the linear model with main effects and interactions. The only deviation between the results of the ANOVA and posthoc tests and the linear model could be found for the factor "type of paper." However, the difference between the mean values of the factor medium was minor (Table 2). Consequently, the choice between the paper substrates seems to be of less importance. The use of PP is recommended, due to the reduced fungal growth and the smaller number of abnormal seedlings in comparison to TP.

\section{Conclusion}

The results of the germination characteristic of $S$. perfoliatum L. indicate that a targeted and optimized pretreatment is required for a fast and complete germination. The germination test method (Table 3 ) includes various treatments for breaking the physiological dormancy. The germination capacity was increased considerably with the use of $\mathrm{GA}_{3}$ solutions, light, alternating temperatures and prechilling, and their modes of action suggest a pronounced physiological dormancy in fresh S. perfoliatum L. seeds. In future experiments, for example, the influence of seed moisture content, harvest date and seed age on dormancy and different seed preparation should be tested and the laboratory-scale results need to be confirmed at field scale. Therefore

Table 3. Resulting germination test method for Silphium perfoliatum L. to exploit the germination potential

Tabelle 3. Resultierende Keimfähigkeitstestmethode für Silphium perfoliatum L. zur Ausschöpfung des Keimfähigkeitspotentials

\begin{tabular}{|c|c|c|c|c|c|c|c|}
\hline Species & Substrate & $\begin{array}{l}\text { Temperature } \\
\left({ }^{\circ} \mathrm{C}\right)\end{array}$ & $\begin{array}{l}\text { First count } \\
\text { (days) }\end{array}$ & $\begin{array}{l}\text { Final count } \\
\text { (days) }\end{array}$ & $\begin{array}{l}\text { Recommendations for } \\
\text { breaking dormancy }\end{array}$ & $\begin{array}{l}\text { Additional } \\
\text { directions }\end{array}$ & Additional advice \\
\hline S. perfoliatum L. & PP & $20 / 30^{*}$ & 7 & 21 & $\mathrm{GA}_{3}$; prechill & - & $\begin{array}{l}\text { prechill } 7 \text { days } / 0^{\circ} \mathrm{C} \text {; } \\
\text { L/D* }\end{array}$ \\
\hline
\end{tabular}

* Alternating temperature and light regime: first temperature 12 hours with light, second temperature 12 hours without light. 
applying additional pretreatments, like other biologically active compounds, priming and pelleting, are of great interest. For this, the results of this work can be incorporated.

\section{Acknowledgments}

The work on S. perfoliatum L. is part of the project "Bioenergy-Silphium," which was funded by the Austrian Climate and Energy Fund and conducted under the program "new energies 2020." The authors gratefully acknowledge Svenia Denise Trölenberg (University of Hohenheim) for supplying seed lot B from Rheinstetten-Forchheim, Germany.

\section{References}

Baskin, C.C. and J.M. Baskin (2014): Seeds: Ecology, Biogeography, and Evolution of Dormancy and Germination. $2^{\text {nd }}$ ed., Academic Press, San Diego, USA.

Baskin, J.M. and C.C. Baskin (2004): A classification system for seed dormancy. Seed Science Research 14, 1-16.

Bauböck, R., Karpenstein-Machan, M. and M. Kappas (2014): Computing the biomass potentials for maize and two alternative energy crops, triticale and cup plant (Silphium perfoliatum L.), with the crop model BioSTAR in the region of Hannover (Germany). Environmental Sciences Europe 26, 1-12.

Table 4. Multiple Comparisons of the selected factors temperature, pretreatment and prechilling Tabelle 4. Mehrfachvergleiche der ausgewählten Faktoren Temperatur, Vorbehandlung und Vorkühlung

\begin{tabular}{llrrrrr}
\hline & & Mean Diff. & Std. & & \multicolumn{2}{c}{$95 \%$ Confidence Interval } \\
(I) temperature & $(\mathrm{J})$ temperature & $(\mathrm{I}-\mathrm{J})$ & Error & Sig. & Lower Bound & Upper Bound \\
\hline $20^{\circ} \mathrm{C}$ & $30^{\circ} \mathrm{C}$ & $-29.87^{*}$ & 0.514 & $<0.001$ & -31.08 & -28.67 \\
& $20<=>30^{\circ} \mathrm{C}$ & -56.56 & 0.514 & $<0.001$ & -57.77 & -55.35 \\
$30^{\circ} \mathrm{C}$ & $20^{\circ} \mathrm{C}$ & 29.87 & 0.514 & $<0.001$ & 28.67 & 31.08 \\
& $20<=>30^{\circ} \mathrm{C}$ & -26.69 & 0.514 & $<0.001$ & -27.89 & -25.48 \\
$20<=>30^{\circ} \mathrm{C}$ & $20^{\circ} \mathrm{C}$ & 56.56 & 0.514 & $<0.001$ & 55.35 & 57.77 \\
& $30^{\circ} \mathrm{C}$ & 26.69 & 0.514 & $<0.001$ & 25.48 & 27.89 \\
$(\mathrm{I})$ pretreatment & $(\mathrm{J})$ pretreatment & & & & & \\
$\mathrm{H}_{2} \mathrm{O}$ & $\mathrm{KNO}_{3}$ & -7.76 & 0.514 & $<0.001$ & -8.96 & -6.55 \\
& $\mathrm{GA}_{3}$ & -16.68 & 0.514 & $<0.001$ & -17.89 & -15.48 \\
$\mathrm{KNO}_{3}$ & $\mathrm{H}_{2} \mathrm{O}$ & 7.76 & 0.514 & $<0.001$ & 6.55 & 8.96 \\
& $\mathrm{GA}{ }_{3}$ & -8.93 & 0.514 & $<0.001$ & -10.13 & -7.72 \\
$\mathrm{GA}{ }_{3}$ & $\mathrm{H}_{2} \mathrm{O}$ & 16.68 & 0.514 & $<0.001$ & 15.48 & 17.89 \\
& $\mathrm{KNO}$ & 8.93 & 0.514 & $<0.001$ & 7.72 & 10.13 \\
$(\mathrm{I})$ prechilling & $(\mathrm{J})$ prechilling & & & & & \\
$\mathrm{no}$ prechilling & $7 \mathrm{~d} / 0^{\circ} \mathrm{C}$ & -22.28 & 0.593 & $<0.001$ & -23.81 & -20.76 \\
& $7 \mathrm{~d} / 5^{\circ} \mathrm{C}$ & -18.39 & 0.593 & $<0.001$ & -19.91 & -16.86 \\
& $7 \mathrm{~d} / 10^{\circ} \mathrm{C}$ & -15.31 & 0.593 & $<0.001$ & -16.84 & -13.79 \\
$7 \mathrm{~d} / 0^{\circ} \mathrm{C}$ & no prechilling & 22.28 & 0.593 & $<0.001$ & 20.76 & 23.81 \\
& $7 \mathrm{~d} / 5^{\circ} \mathrm{C}$ & 3.90 & 0.593 & $<0.001$ & 2.37 & 5.42 \\
& $7 \mathrm{~d} / 10^{\circ} \mathrm{C}$ & 6.97 & 0.593 & $<0.001$ & 5.45 & 8.50 \\
$7 \mathrm{~d} / 5^{\circ} \mathrm{C}$ & no prechilling & 18.39 & 0.593 & $<0.001$ & 16.86 & 19.91 \\
& $7 \mathrm{~d} / 0^{\circ} \mathrm{C}$ & -3.90 & 0.593 & $<0.001$ & -5.42 & -2.37 \\
& $7 \mathrm{~d} / 10^{\circ} \mathrm{C}$ & 3.07 & 0.593 & $<0.001$ & 1.55 & 4.60 \\
$7 \mathrm{~d} / 10^{\circ} \mathrm{C}$ & no prechilling & 15.31 & 0.593 & $<0.001$ & 13.79 & 16.84 \\
& $7 \mathrm{~d} / 0^{\circ} \mathrm{C}$ & -6.97 & 0.593 & $<0.001$ & -8.50 & -5.45 \\
& $7 \mathrm{~d} / 5^{\circ} \mathrm{C}$ & -3.07 & 0.593 & $<0.001$ & -4.60 & -1.55 \\
\hline & & & & & &
\end{tabular}

Based on observed means.

The error term is Mean Square(Error) $=101.407$.

*) The mean difference is significant at the 0.05 level. 
Bewley, J.D. (1997): Seed Germination and Dormancy. The Plant Cell 9, 1055-1066.

Daniel, P. and R. Rompf (1994): Possibilities and limits in the utilization of Silphium perfoliatum as a fodder plant, renewable raw material and a landscape conservation plant. Agribiological research 47, 345-353.

Finch-Savage, W.E. and G. Leubner-Metzger (2006): Seed dormancy and the control of germination. New Phytologist 171, 501-523.

Franzaring, J., Holz, I., Kauf, Z. and A. Fangmeier (2015): Responses of the novel bioenergy plant species Sida hermaphrodita (L.) Rusby and Silphium perfoliatum L. to $\mathrm{CO}_{2}$ fertilization at different temperatures and water supply. Biomass and Bioenergy 81, 574-583.

Franzaring, J., Schmid, I., Bäuerle, L., Gensheimer, G. and A. Fangmeier (2014): Investigations on plant functional traits, epidermal structures and the ecophysiology of the novel bioenergy species Sida hermaphrodita Rusby and Silphium perfoliatum L. Journal of Applied Botany and Food Quality 87, 36-45.

Gansberger, M., Montgomery, L.F.R. and P. Liebhard (2015): Botanical characteristics, crop management and potential of Silphium perfoliatum L. as a renewable resource for biogas production: a review. Industrial Crops and Products 63, 362-372.

ISTA (2015): International Rules for Seed Testing 2015. Chapter 5: The germination test. i-5-56.

Hilhorst, H.W.M. (1995): A critical update on seed dormancy. I. Primary dormancy. Seed Science Research 5, 61-73.

Hilhorst, H.W.M. (1998): The regulation of secondary dormancy. The membrane hypothesis revisited. Seed Science Research 8, 77-90.

Koornneef, M., Bentsink, L. and H. Hilhorst (2002): Seed dormancy and germination. Current Opinion in Plant Biology 5, 33-36.

Kowalski, R. and B. Kędzia (2007): Antibacterial activity of Silphium perfoliatum extracts. Pharmaceutical Biology 45, 494-500.

Kowalski, R. and T. Wolski (2005): The chemical composition of essential oils of Silphium perfoliatum L. Flavour and Fragrance Journal 20, 306-310.

Kucera, B., Cohn, M.A. and G. Leubner-Metzger (2005): Plant hormone interactions during seed dormancy re- lease and germination. Seed Science Research 15, 281307.

Long, R.L., Gorecki, M.J., Renton, M., Scott, J.K., Colville, L., Goggin, D.E., Commander, L.E., Westcott, D.A., Cherry, H. and W.E. Finch-Savage (2014): The ecophysiology of seed persistence: a mechanistic view of the journey to germination or demise. Biological Reviews of the Cambridge Philosophical Society 90, 31-59.

Mast, B., Lemmer, A., Oechsner, H., Reinhardt-Hanisch, A., Claupein, W. and S. Graeff-Hönninger (2014): Methane yield potential of novel perennial biogas crops influenced by harvest date. Industrial Crops and Products 58, 194-203.

Neumerkel, W. and B. Märtin (1982): Silphium (Silphium perfoliatum L.) - a new feed plant. Archives of Agronomy and Soil Science 26, 261-271.

Niqueux, M. (1981): A new forage plant: Silphium perfoliatum L. Fourrages 87, 119-136.

Oh, E., Yamaguchi, S., Kamiya, Y., Bae, G., Chung, W.I. and G. Choi (2006): Light activates the degradation of PIL5 protein to promote seed germination through gibberellin in Arabidopsis. The Plant Journal 47, 124-139.

Sokolov, V.S. and Z.I. Gritsak (1972): Silphium - a valuable fodder and nectariferous crop. World Crops 24, 299-301.

Trölenberg, S.D., Kruse, M. and A. Jonitz (2012): Verbesserung der Saatgutqualitätbei der Durchwachsenen Silphie (Silphium perfoliatum L.). VDLUFA-Verlag, Darmstadt, Germany.

Troxler, J. and R. Daccord (1982): Silphium perfoliatum L.: An interesting fodder? Revue Suisse d'Agriculture 14, 279-281.

Vetter, A., Conrad, M. and A. Biertümpfel (2010): Optimierung des Anbauverfahrens für Durchwachsene Silphie (Silphium perfoliatum L.) als Kofermentpflanze in Biogasanlagen sowie Überführung in die landwirtschaftliche Praxis. Thüringer Landesanstalt für Landwirtschaft, Jena, Germany.

Zhang, X., Xia, H., Li, Z., Zhuang, P. and B. Gao (2010): Potential of four forage grasses in remediation of $\mathrm{Cd}$ and $\mathrm{Zn}$ contaminated soils. Bioresource Technology 101, 2063-2066. 